\title{
Transforming into Sustainable Innovation-driven Digital Co-creation: The Role of Experience, Community and Agility
}

\author{
Leonardus W Wasono Mihardjo, Sasmoko, Firdaus Alamsjah, Riza A.N. Rukmana
}

\begin{abstract}
Sustainability is a critical element in creating long-term values for service creation, especially for in-service providers in the Information Communication and Technology (ICT) industry. Sustainable values through co-creation involve crucial stakeholders, especially customers, organizations, and social communities to maximise the captured total value. Past studies have explored the concept, system and role of those stakeholders, however the sustainability of co-creation in the digital era has not been covered. Therefore, this paper aims to provide an understanding of the key concepts and models that would support practitioners in building sustainable innovation-driven digital co-creation. The study was conducted using 195 samples representing Indonesian ICT firms. Findings demonstrate that digital co-creation plays a significant role as an intervening variable in the relationship between customer experience orientation, social community, and organization agility and transformational performance.
\end{abstract}

Index Terms: organizational agility, social community, customer experience orientation, digital co-creation, sustainability.

\section{INTRODUCTION}

The advancement of the Internet, mobile, cloud, and computing technology in industry 4.0 brings a huge impact on the opening of markets globally. It also shortens the product lifecycle and enables new entries into market. This leads to firms having to look out for other sources of value outside of the company to be able to innovate as well as sustain the competitiveness within the market. The source of value could be created out of the firm's agile capabilities in order for the organisation to adapt to the changes (Arbussa, Bikfalvi, and Marquès, 2017; Teece, Peteratd, and Leih, 2016). An organisation's agility involves some critical components such as people (Crocitto and Youssef, 2003), culture (Carvalho, Sampaio, Rebentisch, Carvalho, and Saraiva, 2017; Felipe and Rold, 2017), and process (Seethamraju and Krishna Sundar, 2013). Organization

\footnotetext{
Revised Manuscript Received on September 22, 2019.

Leonardus W Wasono Mihardjo, School of Business, Bina Nusantara University, Jakarta, Indonesia.

Sasmoko, Primary Teacher Education Departmeny, Bina Nusantara University, Jakarta, Indonesia. Email: sasmoko@binus.edu

Firdaus Alamsjah, , School of Business, Bina Nusantara University, Jakarta, Indonesia.

Riza A.N. Rukmana, Industrial Engineering Department, Telkom University, Bandung, Indonesia.
}

agility and digital technology also results in social communities becoming a more important and popular source for value creation. It also allows for collaborations through co-creation in the digital era (Richter, Trier, and Richter, 2017; Wüstenhagen, Sharma, Starik, and Wuebker, 2008).

Social communities in this study refer to communities with a purpose to create innovative values for the company and its customers. It includes online communities shaped through virtual relationships (Füller, Bartl, Ernst, and Mühlbacher, 2006) and communities shaped through real, physical relationships.

Another source of value in shaping co-creation comes from customer experience, which takes on a crucial role in creating value (Sjödin and Kristensson, 2012). Customer experience focuses on the firm's capability to provide a solid customer journey to realise their needs (Lemon and Verhoef, 2016; Ramaswamy, 2011). This makes customer experience central in the development of digital co-creation that involves customers in the company's process of innovation. Fuller (2010) in a past study has clearly defined the boundaries and roles between firms and its customers. He identifies how in a co-creation concept, the customers are highly involved and are highly appreciated for their participation and creativity for the company. Platforms today in the digital era enables for collaboration and participation from customers by using their knowledge to maintain a long lasting relationship with the company and help shape its culture (Sawhney, Verona, Prandelli, 2005; Vincenza Ciasullo, Troisi, Cosimato, 2018). Cultural changes also leads to capabilities transformation, particularly in terms of processes modernization. The measurement of performance during this transformation is also known as transformational performance (Wei and Xuexun, 2010).

Past studies on creating the value of co-creation mostly focus on how companies sustain existing performances through creating, delivering, and capturing economic value. However, they mostly are limited to or less focused on social values. Since incumbent firms are facing a hard time to deliver and sustain an effective customer experience through digital technology (Loucks, Bradley, Macaulay, Noronha, and Wade, 2015; Pérez, Dos Santos Paulino, and Cambra-Fierro, 2017), they would need to have a wider range of stakeholders that emphasises on social communities. They are also required to raise the need for

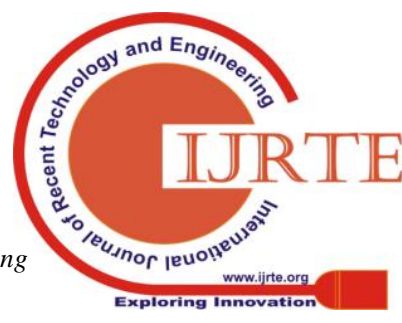


sustainable value creation.

This study focuses on the development of digital co-creation based on the development of social communities, customer experience orientation, and organizational agility to boost transformational performance in the Indonesian ICT industry to head towards a more sustainable development. Findings of this study are applicable in the ICT industry, especially with the rise of companies going green and more environmentally friendly, particularly in use of power consumption. This also applies to the rapid growth of online communities as well as contributing to literature on digital transformation models. The ICT industry is important, given its predominance in generating values of economic growth and strengthening the competitive advantage of a country (Pradhan, Mallik, and Bagchi, 2018).

This paper includes review of relevant literature, hypotheses, research methodology, results, and a discussion of the results and findings that also includes implications on the digital transformation model as well as its limitations and suggestions for future studies.

\section{LITERATURE REVIEW}

The development of co-creation innovation in forming a sustainable development requires incremental innovation as well as the change paradigm through transformation (Ramaswamy, 2009; Trencher et al., 2017). To ensure that the transformation phase drives changes, it also requires a new measurement on transformational performance by integrating concept of digital maturity (Valdez-de-leon, 2016) and performance management (Latham, 2013). It should also have a balance between the existing and potential performance based on innovation and development of ecosystem performance to support the digital transformation (Wei and Xuexun, 2010). Transformational performance derives from the sustainable business strategic matrix (Voglander et al, 2014), in which it should not only rely on the economic value, but capturing all the values including the social values, as illustrated in Figure 1 (Wüstenhagen et al., 2008).

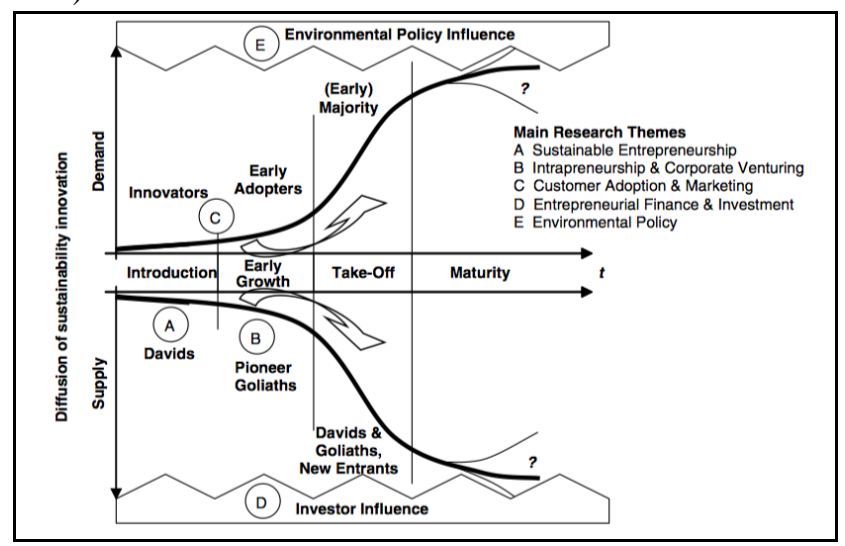

Figure 1. Sustainable innovation-driven co-creation and customer experience

(Wüstenhagen et al., 2008)
Wuestenhagen, et al. (2008) provides the framework of a whole system that helps firms to understand more about long-term sustainability. It helps firms to focus on where to start the changes as well as understand all the parties involved and how they interact. This is important, as it could help identify more opportunities to create sustainable value.

\begin{tabular}{|c|c|c|}
\hline & $\begin{array}{l}\text { Value Co-Creation } \\
\text { Strategy Definition }\end{array}$ & \\
\hline $\begin{array}{l}\text { Co-Creators Targeting } \\
\text { (Business Allies) }\end{array}$ & \multirow{2}{*}{25} & $\begin{array}{l}\text { Co-Creators Targeting } \\
\text { (Customers) }\end{array}$ \\
\hline$\rightleftharpoons \quad 5$ & & $\rightleftharpoons \quad 5$ \\
\hline \multicolumn{3}{|c|}{ Experience-Centric Network } \\
\hline $\begin{array}{c}\text { Collaborative Networked } \\
\text { Organisations }\end{array}$ & & $\begin{array}{l}\text { Customer } \\
\text { Communities }\end{array}$ \\
\hline $3 \square$ & $\square \quad \square$ & 5 \\
\hline $\begin{array}{l}\text { Trust } \\
\text { Building }\end{array}$ & $\begin{array}{l}\text { Capabilities } \\
\text { Provisioning }\end{array}$ & $\begin{array}{l}\text { Rewarding } \\
\text { Mechanisms }\end{array}$ \\
\hline
\end{tabular}

Figure 2. The value co-creation framework (Romero and

$$
\text { Molina, 2009) }
$$

Romero and Molino (2009) enrich the way in capturing value co-creation in terms of co-creating experience for a more sustainable development. Digital co-creation consists of the strategy in creating value co-creation including the development of vision, capability, and tactical implementation. Creating co-creation-experience also requires the development of experience ecosystem, which is highly determined by interactions and collaborations between multiple experience channels that allow customers to shape their own experiences. This includes the forming of social communities through virtual and physical interactions. To support the experience-centric network, the organizational agility is also important in building trust, capability, and reward mechanism. The agility of an organization itself is defined as the operational capabilities to adapt to changes as fast as the market or customer requirements. This also provides flexibility to adjust its internal structures and processes in response to the changes (Trinh-Phuong, Molla, and Peszynski, 2010).

Organizational agility consists of people agility, process agility in adapting to change, and culture agility (Crocitto and Youssef, 2003; Nold and Michel, 2013). Through the digitization process, organizational agility has significant influence in shifting manual processes to be automated in order to step up a company's processes internally and boost the firm's performance (Chakravarty, Grewal, and Sambamurthy, 2013; Lu and Ramamyrthy, 2011). Therefore, the first hypothesis is formulated as the following:

Hypothesis 1: Organizational agility has a significant impact on transformation performance

Past studies have shown that organizational agility creates an environment that enables collaboration and encourages the creation of digital co-creation between customers and firms (Sharma, Conduit, and Hill, 2014). Romero and Molino (2009) have found in their study that there is a significant link between organizations and social

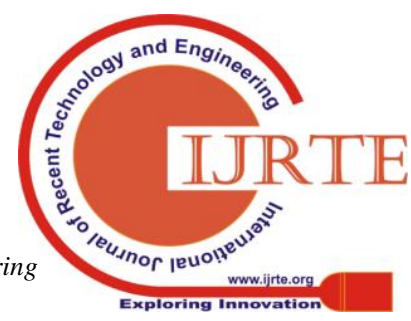


communities to perform co-creation value. Online communities provide companies with new interaction channels to co-create value by involving enthusiastic consumers that would be difficult to reach without the support of technologies (Richter et al., 2017). Choosing the right channels to target the right co-creators is important in order to perform creation partnerships with customers and provide them with new experiences. Not all customers can be good co-creators, it depends on the knowledge, skills, expertise, and behaviours while undergoing co-creation, especially in digital era (Mittal, 2014; Shrivastava, 2016; Sjödin and Kristensson, 2012). Hence, the third hypothesis is formulated as the following:

Hypothesis 2: Organizational agility, social communities and customer experience orientation has a significant impact on digital co-creation.

Firms that focus on customer experience could leverage its overall performance (Fatma, 2014; Mihardjo, Sasmoko, Alamsjah, and Elidjen, 2019), and digital co-creation is strongly correlated to firm performance, especially at a transformational stage (Hamidi and Shams Gharneh, 2017; Mihardjo, Alamsjah, Elidjen, and Sasmoko, 2018; Restuccia, 2009). The past studies lead to the formulation of the last two hypotheses:

Hypothesis 3: Customer experience orientation has a significant impact on transformational performance

\section{Hypothesis 4: Digital co-creation has a significant impact on transformational performance}

The research model for the current study is demonstrated in Figure 3.

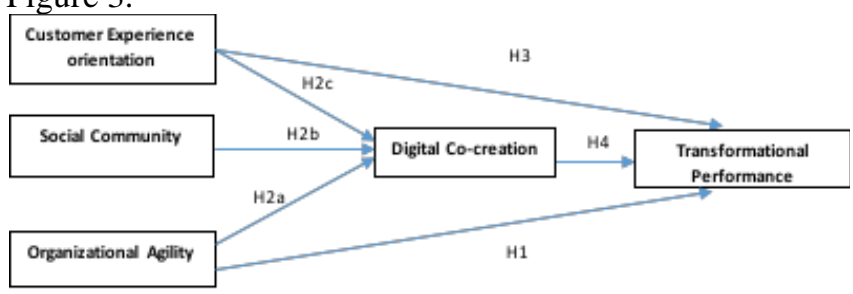

Figure 3. Research model

\section{METHOD}

\section{Research design:}

The research design used to assess the sustainable co-creation model with a focus on the relationship between organizational agility, social community, and customer experience orientation with digital co-creation to boost transformational performance in the Indonesian ICT sector.

\section{Population and sample:}

377 ICT firms are currently operating in Indonesia according to the Ministry of Information and Communication (2017), which is the population of the current study, which consists of service providers. According to Slovin's (1960) calculations, an appropriate sample size for a study such as the current one would be 195 firms, with $0.05 \%$ error rate. This sample is higher than minimum rule of thumb for sample selection amounting to 35 samples (Cohen, 1992). Smart PLS was used to analyse and process the collected data.

\section{Sampling method:}

Simple random sampling was used to allow respondents to have equal chances to be selected for data collection (Hair, Ringle, Sarstedt, and Vinzi, 2014), with the firms as the units of analyses. A seven-point Likert scale ranging from 1 ('Not at all satisfied') to 7 (very satisfied') was used to examine the response for each construct of the study.

\section{RESUlt}

The comparison result of completion rate and single easy question test between diaspora Indonesia in Malaysia and Indonesia can be shown in Table 1 . The completion rate indicates the users accomplishment task in certain time and single easy question (SEQ) is questionnaire result of the user perception when using the applications.

Table 1. The Result of Completion Rate and SEQ

\begin{tabular}{|c|c|c|c|c|c|}
\hline \multirow{2}{*}{\multicolumn{2}{|c|}{ Test Items }} & \multicolumn{2}{|c|}{ Malaysia } & \multicolumn{2}{|c|}{ Indonesia } \\
\hline & & \multirow{2}{*}{$\begin{array}{c}\begin{array}{c}\text { Completion } \\
\text { Rate }\end{array} \\
0 \%\end{array}$} & \multirow{2}{*}{$\begin{array}{c}\begin{array}{c}\text { Single } \\
\text { Easy } \\
\text { Question }\end{array} \\
4\end{array}$} & \multirow{2}{*}{$\begin{array}{c}\begin{array}{c}\text { Completi } \\
\text { on Rate }\end{array} \\
0 \%\end{array}$} & \multirow{2}{*}{$\begin{array}{c}\begin{array}{c}\text { Single } \\
\text { Easy } \\
\text { Questi } \\
\text { on }\end{array} \\
5\end{array}$} \\
\hline 1 & Voice call & & & & \\
\hline 2 & SMS call & $50 \%$ & 4.6 & $50 \%$ & 5.5 \\
\hline 3 & Free chat & $20 \%$ & 2.8 & $20 \%$ & 4 \\
\hline 4 & Video Call & $0 \%$ & 3.5 & $0 \%$ & 2 \\
\hline 5 & Check of balance & $70 \%$ & 5.5 & $70 \%$ & 6 \\
\hline 6 & $\begin{array}{l}\text { Voice package } \\
\text { purchasing }\end{array}$ & $70 \%$ & 5.5 & $60 \%$ & 4.5 \\
\hline 7 & $\begin{array}{l}\text { SMS package } \\
\text { purchasing }\end{array}$ & $70 \%$ & 4.8 & $60 \%$ & 4.8 \\
\hline 8 & IDD Call & $80 \%$ & 6.3 & $80 \%$ & 6.5 \\
\hline 9 & $\begin{array}{l}\text { Transfer balance } \\
\text { apps }\end{array}$ & $70 \%$ & 4 & $50 \%$ & 3 \\
\hline 10 & $\begin{array}{l}\text { Transfer balance } \\
\text { Operators }\end{array}$ & $70 \%$ & 4.5 & $50 \%$ & 5 \\
\hline 11 & $\begin{array}{l}\text { Prepaid electricity } \\
\text { payment }\end{array}$ & $10 \%$ & 3 & $10 \%$ & 4 \\
\hline
\end{tabular}

Based on the data The System Usability Score, the result shows that the score of Indonesia diaspora in Malaysia was $44 \%$ while score in Indonesia was $39 \%$ less than expected SUS score on $68 \%$ and NPS score for diaspora Indonesia in Malaysia and Indonesia was 0 and $10 \%$ respectively less than average NPS application was 31\% (Telin, 2019)

Figure 4 shows the result of measurement test using SEM PLS. To validate the latent variables, dimensions, and indicators, the measurements test was conducted to ensure the consistency, reliability, and validity of respective variables, dimensions, and indicators. The loading factors of Cronbach's Alpha (CA) and composite reliability

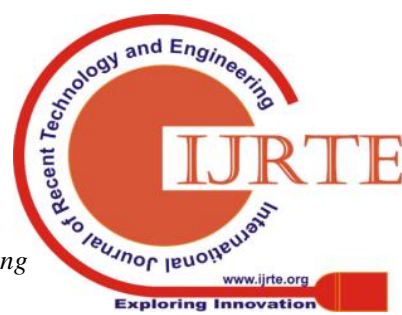


(CR) above 0.7 are used to determine the reliability and validity. The average variance extracted (AVE) also exceeds the discriminant validity as demonstrated in Table 2 below 0.5 . The overall results are shown in Table 1. Assessment on uses a cross loading test, in which the values should be higher than 0.6 .

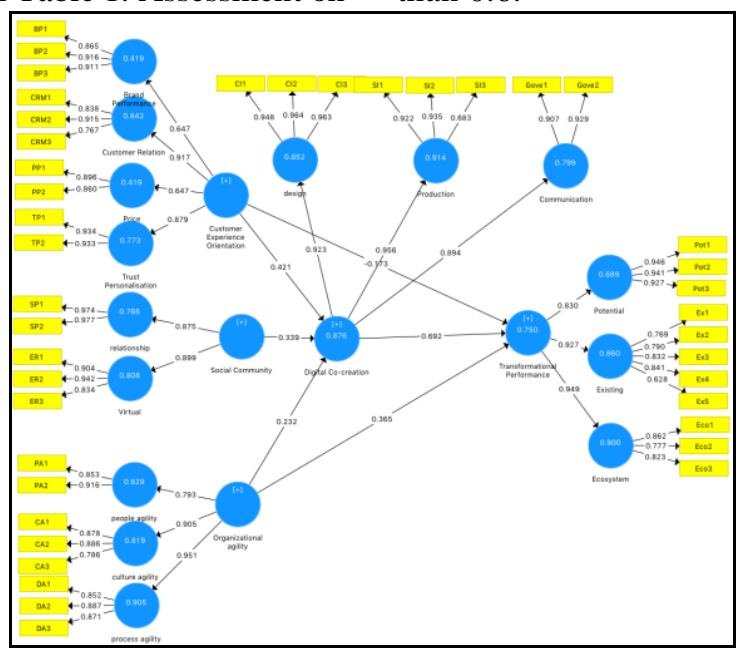

Figure 4. Measurement Result

Table 2. Construct Reliability and Validity

\begin{tabular}{|r|l|r|c|c|c|c|c|}
\hline No & \multicolumn{1}{|c|}{ Variables } & $\mathbf{1}$ & $\mathbf{2}$ & $\mathbf{3}$ & $\mathbf{4}$ & $\mathbf{5}$ & Remarks \\
\hline 1 & Organizational agility & $\begin{array}{r}0.78 \\
8\end{array}$ & & & & & Valid \\
\hline 2 & Operational Efficiency & $\begin{array}{r}0.78 \\
0\end{array}$ & 0.815 & & & & Valid \\
\hline 3 & Customer Experience Orientation & $\begin{array}{r}0.75 \\
9\end{array}$ & 0.806 & 0.877 & & & Valid \\
\hline 4 & Business Model Innovation & $\begin{array}{r}0.78 \\
5\end{array}$ & 0.803 & 0.845 & $\begin{array}{r}0.90 \\
0\end{array}$ & Valid \\
\hline 5 & Transformational Performance & $\begin{array}{r}0.76 \\
9\end{array}$ & 0.793 & 0.834 & $\begin{array}{r}0.86 \\
1\end{array}$ & $\begin{array}{r}0.86 \\
6\end{array}$ \\
\hline
\end{tabular}

Table 2. Cross Loading test result

\begin{tabular}{|c|c|c|c|c|c|c|c|c|c|c|c|c|c|c|c|}
\hline & $\begin{array}{c}\text { Brand } \\
\text { Perf }\end{array}$ & $\begin{array}{c}\text { Com } \\
\text { munic } \\
\text { ation }\end{array}$ & $\begin{array}{c}\text { Custo } \\
\text { mer } \\
\text { Relati } \\
\text { on } \\
\end{array}$ & $\begin{array}{c}\text { Ecosyste } \\
\mathbf{m}\end{array}$ & $\begin{array}{c}\text { Existin } \\
\mathrm{g}\end{array}$ & $\begin{array}{c}\text { Potent } \\
\text { ial }\end{array}$ & Price & $\begin{array}{c}\text { Prod } \\
\text { uctio } \\
\text { n }\end{array}$ & $\begin{array}{c}\text { Trust } \\
\text { Person } \\
\text { al } \\
\end{array}$ & $\begin{array}{c}\text { Virtu } \\
\text { al }\end{array}$ & $\begin{array}{c}\text { Cult } \\
\text { ure } \\
\text { Agili } \\
\text { ty } \\
\end{array}$ & $\begin{array}{c}\text { Desig } \\
\text { n }\end{array}$ & $\begin{array}{l}\text { People } \\
\text { Agility }\end{array}$ & $\begin{array}{c}\text { Proces } \\
\text { S } \\
\text { Agility }\end{array}$ & $\begin{array}{c}\text { Relationshi } \\
\text { p }\end{array}$ \\
\hline BP1 & 0.865 & 0.443 & 0.3 & 0.049 & 0.427 & 0.316 & 0.545 & 0.165 & 0.215 & 0.339 & 0.349 & 0.171 & 0.054 & 0.305 & 0.323 \\
\hline BP2 & 0.916 & 0.647 & 0.601 & 0.248 & 0.609 & 0.505 & 0.383 & 0.442 & 0.369 & 0.338 & 0.609 & 0.293 & 0.312 & 0.588 & 0.547 \\
\hline BP3 & 0.911 & 0.535 & 0.489 & 0.165 & 0.561 & 0.441 & 0.411 & 0.396 & 0.38 & 0.34 & 0.524 & 0.315 & 0.189 & 0.433 & 0.491 \\
\hline CA1 & 0.357 & 0.427 & 0.507 & 0.484 & 0.492 & 0.629 & 0.297 & 0.53 & 0.365 & 0.425 & 0.878 & 0.442 & 0.62 & 0.758 & 0.544 \\
\hline $\mathrm{CA2}$ & 0.491 & 0.337 & 0.394 & 0.278 & 0.423 & 0.491 & 0.182 & 0.396 & 0.255 & 0.18 & 0.886 & 0.229 & 0.38 & 0.707 & 0.449 \\
\hline $\mathrm{CA3}$ & 0.592 & 0.74 & 0.576 & 0.535 & 0.688 & 0.789 & 0.478 & 0.675 & 0.463 & 0.47 & 0.786 & 0.575 & 0.517 & 0.799 & 0.781 \\
\hline CI1 & 0.118 & 0.604 & 0.62 & 0.569 & 0.512 & 0.529 & 0.559 & 0.75 & 0.753 & 0.644 & 0.425 & 0.948 & 0.519 & 0.497 & 0.616 \\
\hline CI2 & 0.331 & 0.776 & 0.688 & 0.668 & 0.675 & 0.591 & 0.606 & 0.855 & 0.824 & 0.719 & 0.471 & 0.964 & 0.476 & 0.541 & 0.706 \\
\hline $\begin{array}{l}\text { CRM } \\
1\end{array}$ & 0.418 & 0.519 & 0.838 & 0.392 & 0.484 & 0.667 & 0.356 & 0.648 & 0.526 & 0.482 & 0.569 & 0.603 & 0.616 & 0.648 & 0.716 \\
\hline $\begin{array}{l}\text { CRM } \\
2\end{array}$ & 0.273 & 0.444 & 0.915 & 0.444 & 0.422 & 0.582 & 0.351 & 0.735 & 0.735 & 0.475 & 0.47 & 0.681 & 0.609 & 0.577 & 0.672 \\
\hline $\begin{array}{l}\text { CRM } \\
3\end{array}$ & 0.667 & 0.609 & 0.767 & 0.448 & 0.677 & 0.455 & 0.52 & 0.562 & 0.672 & 0.587 & 0.451 & 0.508 & 0.428 & 0.438 & 0.509 \\
\hline DA1 & 0.316 & 0.469 & 0.485 & 0.517 & 0.487 & 0.712 & 0.021 & 0.558 & 0.242 & 0.195 & 0.717 & 0.372 & 0.592 & 0.852 & 0.546 \\
\hline DA2 & 0.404 & 0.681 & 0.63 & 0.524 & 0.545 & 0.737 & 0.397 & 0.74 & 0.521 & 0.362 & 0.771 & 0.685 & 0.632 & 0.887 & 0.73 \\
\hline
\end{tabular}


International Journal of Recent Technology and Engineering (IJRTE) ISSN: 2277-3878, Volume-8 Issue-2S9, September 2019

\begin{tabular}{|c|c|c|c|c|c|c|c|c|c|c|c|c|c|c|c|}
\hline DA3 & 0.604 & 0.592 & 0.592 & 0.477 & 0.658 & 0.797 & 0.407 & 0.634 & 0.431 & 0.441 & 0.844 & 0.438 & 0.56 & 0.871 & 0.743 \\
\hline ER1 & 0.373 & 0.515 & 0.425 & 0.544 & 0.582 & 0.336 & 0.638 & 0.429 & 0.45 & 0.904 & 0.306 & 0.486 & 0.447 & 0.225 & 0.464 \\
\hline ER2 & 0.435 & 0.647 & 0.528 & 0.594 & 0.695 & 0.449 & 0.654 & 0.505 & 0.55 & 0.942 & 0.439 & 0.565 & 0.554 & 0.334 & 0.554 \\
\hline ER3 & 0.211 & 0.668 & 0.665 & 0.64 & 0.573 & 0.592 & 0.62 & 0.692 & 0.788 & 0.834 & 0.408 & 0.871 & 0.587 & 0.457 & 0.712 \\
\hline Eco1 & 0.126 & 0.517 & 0.245 & 0.862 & 0.706 & 0.619 & 0.316 & 0.467 & 0.283 & 0.497 & 0.424 & 0.403 & 0.482 & 0.491 & 0.522 \\
\hline Eco2 & 0.27 & 0.646 & 0.677 & 0.777 & 0.713 & 0.685 & 0.319 & 0.781 & 0.753 & 0.555 & 0.584 & 0.743 & 0.618 & 0.637 & 0.752 \\
\hline$E \operatorname{co3}$ & 0.061 & 0.466 & 0.346 & 0.823 & 0.624 & 0.37 & 0.34 & 0.503 & 0.382 & 0.602 & 0.267 & 0.5 & 0.426 & 0.292 & 0.383 \\
\hline Ex1 & 0.528 & 0.769 & 0.561 & 0.611 & 0.789 & 0.598 & 0.534 & 0.689 & 0.572 & 0.743 & 0.514 & 0.662 & 0.438 & 0.493 & 0.659 \\
\hline Ex2 & 0.295 & 0.623 & 0.417 & 0.778 & 0.79 & 0.587 & 0.453 & 0.511 & 0.488 & 0.55 & 0.454 & 0.543 & 0.378 & 0.461 & 0.5 \\
\hline Ex3 & 0.34 & 0.629 & 0.479 & 0.767 & 0.832 & 0.688 & 0.343 & 0.638 & 0.418 & 0.435 & 0.52 & 0.555 & 0.503 & 0.645 & 0.652 \\
\hline Ex4 & 0.734 & 0.745 & 0.634 & 0.56 & 0.841 & 0.693 & 0.382 & 0.595 & 0.424 & 0.571 & 0.542 & 0.443 & 0.517 & 0.551 & 0.714 \\
\hline Ex5 & 0.617 & 0.506 & 0.335 & 0.394 & 0.628 & 0.308 & 0.4 & 0.347 & 0.395 & 0.374 & 0.49 & 0.299 & 0.191 & 0.3 & 0.376 \\
\hline Gove1 & 0.71 & 0.907 & 0.52 & 0.522 & 0.78 & 0.729 & 0.595 & 0.653 & 0.48 & 0.543 & 0.584 & 0.581 & 0.356 & 0.606 & 0.709 \\
\hline Gove2 & 0.44 & 0.929 & 0.618 & 0.684 & 0.781 & 0.676 & 0.459 & 0.733 & 0.623 & 0.712 & 0.533 & 0.796 & 0.611 & 0.628 & 0.717 \\
\hline PA1 & 0.252 & 0.45 & 0.478 & 0.582 & 0.511 & 0.394 & 0.27 & 0.434 & 0.362 & 0.586 & 0.468 & 0.44 & 0.853 & 0.465 & 0.424 \\
\hline PA2 & 0.16 & 0.495 & 0.661 & 0.528 & 0.458 & 0.726 & 0.143 & 0.638 & 0.356 & 0.49 & 0.59 & 0.518 & 0.916 & 0.717 & 0.66 \\
\hline PP1 & 0.352 & 0.504 & 0.46 & 0.449 & 0.527 & 0.352 & 0.896 & 0.445 & 0.634 & 0.689 & 0.403 & 0.62 & 0.315 & 0.317 & 0.477 \\
\hline PP2 & 0.505 & 0.494 & 0.393 & 0.23 & 0.409 & 0.264 & 0.86 & 0.302 & 0.508 & 0.559 & 0.27 & 0.469 & 0.059 & 0.252 & 0.343 \\
\hline Pot1 & 0.37 & 0.682 & 0.636 & 0.625 & 0.658 & 0.946 & 0.372 & 0.76 & 0.446 & 0.533 & 0.729 & 0.639 & 0.689 & 0.826 & 0.852 \\
\hline Pot2 & 0.482 & 0.688 & 0.644 & 0.651 & 0.721 & 0.941 & 0.286 & 0.723 & 0.452 & 0.43 & 0.725 & 0.545 & 0.55 & 0.808 & 0.79 \\
\hline Pot3 & 0.502 & 0.776 & 0.614 & 0.652 & 0.771 & 0.927 & 0.337 & 0.806 & 0.474 & 0.508 & 0.69 & 0.598 & 0.603 & 0.788 & 0.882 \\
\hline SI1 & 0.39 & 0.776 & 0.729 & 0.703 & 0.75 & 0.849 & 0.374 & 0.922 & 0.629 & 0.603 & 0.598 & 0.779 & 0.703 & 0.759 & 0.901 \\
\hline SI2 & 0.345 & 0.695 & 0.735 & 0.584 & 0.634 & 0.718 & 0.358 & 0.935 & 0.721 & 0.526 & 0.521 & 0.834 & 0.509 & 0.626 & 0.836 \\
\hline SI3 & 0.264 & 0.418 & 0.484 & 0.524 & 0.457 & 0.472 & 0.394 & 0.683 & 0.442 & 0.442 & 0.54 & 0.56 & 0.325 & 0.5 & 0.47 \\
\hline SP1 & 0.538 & 0.746 & 0.751 & 0.601 & 0.696 & 0.894 & 0.453 & 0.846 & 0.649 & 0.595 & 0.682 & 0.708 & 0.583 & 0.76 & 0.974 \\
\hline SP2 & 0.483 & 0.768 & 0.713 & 0.713 & 0.78 & 0.859 & 0.466 & 0.882 & 0.648 & 0.68 & 0.703 & 0.74 & 0.639 & 0.759 & 0.977 \\
\hline TP1 & 0.381 & 0.588 & 0.721 & 0.483 & 0.565 & 0.472 & 0.645 & 0.62 & 0.934 & 0.6 & 0.378 & 0.763 & 0.384 & 0.432 & 0.629 \\
\hline TP2 & 0.311 & 0.542 & 0.719 & 0.585 & 0.538 & 0.439 & 0.577 & 0.708 & 0.933 & 0.669 & 0.433 & 0.792 & 0.369 & 0.434 & 0.612 \\
\hline
\end{tabular}

Table 1 and table 2 demonstrate that the all variables, dimensions, and indicators are valid, therefore direct hypotheses testing can be performed to assess the direct significant relationships between two latent variables.

H1: The first hypothesis examines the relationship between organizational agility and transformational performance. Tests show that the $\mathrm{t}$-value is 2.222 and $\mathrm{p}<0.05$, therefore $\mathrm{H} 1$ is accepted.

H2: Investigations on the relationship between 'organizational agility and digital co-creation' 'and digital co-creation' and 'customer experience orientation and digital co-creation', consisting of $\mathrm{H} 2 \mathrm{a}, \mathrm{H} 2 \mathrm{~b}, \mathrm{H} 2 \mathrm{c}$, respectively. Results show the t-values and $p$-values as 2.337 and $p<0.005$,
2.134 and $\mathrm{p}<0.05$ and, 2.153 and $\mathrm{p}<0.05$ respectively; therefore, $\mathrm{H} 2 \mathrm{a}, \mathrm{H} 2 \mathrm{~b}, \mathrm{H} 2 \mathrm{c}$ is accepted.

H3: The third hypothesis investigates the relationship between customer experience orientation and transformational performance, with results showing the $\mathrm{t}$-value as 0.836 and $\mathrm{p}>0.005$; therefore, $\mathrm{H} 3$ is rejected.

H4: The fourth hypothesis investigates the relationship between digital co-creation and transformational performance, with results showing the t-value as 2.963 and $\mathrm{p}>0.005$; therefore, $\mathrm{H} 4$ is accepted.

The overall research model based on SEM-PLS can be shown in Figure 5. 


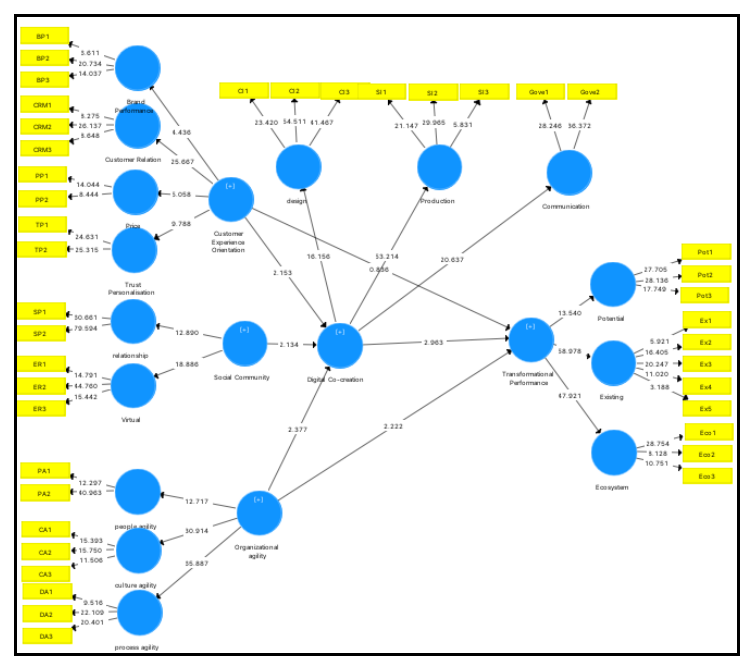

Figure 5. Research model Result

The Table 3 below demonstrates the direct relationships within the study.

Table 3. Direct hypothesis testing Result

\begin{tabular}{|c|c|c|c|c|c|}
\hline & Hypothesis & Standard Deviation & T Statistics & P Values & Remarks \\
\hline 1 & Organizational agility $->$ Transformational Performance & 0.166 & 2.222 & 0.026 & Significant \\
\hline $2 \mathrm{a}$ & Organizational agility $\rightarrow$ Digital Co-creation & 0.099 & 2.337 & 0.018 & Significant \\
\hline $2 \mathrm{~b}$ & Social Community -> Digital Co-creation & 0.159 & 2.134 & 0.033 & Significant \\
\hline $2 \mathrm{c}$ & Customer Experience Orientation -> Digital Co-creation & 0.193 & 2.153 & 0.032 & Significant \\
\hline 3 & $\begin{array}{c}\text { Customer Experience Orientation -> Transformational } \\
\text { Performance }\end{array}$ & 0.206 & 0.836 & 0.404 & No Significant \\
\hline 4 & Digital Co-creation -> Transformational Performance & 0.232 & 2.963 & 0.003 & Significant \\
\hline
\end{tabular}

The next step investigates the mediating relationship according the research model to assess the indirect effects, shown in table 4.

Table 4. indirect hypothesis testing Result

\begin{tabular}{|c|c|c|c|c|}
\hline Hypothesis & $\begin{array}{c}\text { Standard } \\
\text { Deviation }\end{array}$ & T Statistics & P Values & Remarks \\
\hline $\begin{array}{c}\text { Organizational agility -> Digital Co-creation } \\
\text {-> Transformational Performance }\end{array}$ & 0.146 & 1.965 & 0.050 & $\begin{array}{c}\text { Significan } \\
\mathrm{t}\end{array}$ \\
\hline $\begin{array}{c}\text { Social Community -> Digital Co-creation -> } \\
\text { Transformational Performance }\end{array}$ & 0.136 & 1.958 & 0.050 & $\begin{array}{c}\text { Significan } \\
\mathrm{t}\end{array}$ \\
\hline $\begin{array}{c}\text { Customer Experience Orientation -> Digital } \\
\text { Co-creation -> Transformational Performance }\end{array}$ & 0.137 & 1.977 & 0.048 & $\begin{array}{c}\text { Significan } \\
\mathrm{t}\end{array}$ \\
\hline
\end{tabular}

Table 4 demonstrates the role of digital co-creation as a central intervening variable to shape the relationships between organizational agility, social community, and customer experience orientation with transformational performance.

\section{DisCUSSION}

Findings of the current study have implications on the model of sustainability in a digital transformation as shown in Figure 6. The model consists of 3 parts:

The first part consists of social community, which shows how social community has a significant influence in the development of digital co-creation. Therefore, in order to capture value creation, firms would require improving the quality of decisions, which should not only be based on economic values. These decisions need to have a more diverse viewpoint, which could potentially lead to a better understanding of the challenge to be able to think outside of the box and take social communities into consideration. Based on the findings, virtual or online communities have a higher, significant impact on digital co-creation. This shows how the development of digital co-creation can effectively improve. Integrating communication policies through multiple channels, including online and physical communities would be one way to make this possible. 
The second part of the model is related to the shaping of collaborations and experience through digital co-creation. Findings show that the experience of a customer can be developed with significant impact when companies have a close relationship with them. Customer experience orientation enables for technological platform collaborations to expand to any size and scale to offer the best products and services. Whereas building a good customer relationship would place customers as co-creators. This allows them to share their knowledge and creativity as a trusted partner to support brand performance. To perform experience-collaboration in digital co-creation, organizational agility as a term of process and cultural perspective has a significant influence in shaping collaboration in order to support the development of sustainability policy.

Other than that, findings also show that social communities are also an influence in pushing companies to take an action from the top management. This involves diverse stakeholders in a constructive dialogue and autonomy as part of organizational success.

The third circle is sustainability and firm adaptability. Being involved with diverse stakeholders in the decision and design process of new processes, methodology, people, culture development to perform the organizational agility could enable the firm to act on the holistic matter to perform adaptability and sustainability in the longer term. The firm has the capability to 'adapt' to the changing circumstances. However, they still contribute to the initial strategy that they were a part of by taking the feedback from any diverse stakeholders into consideration.

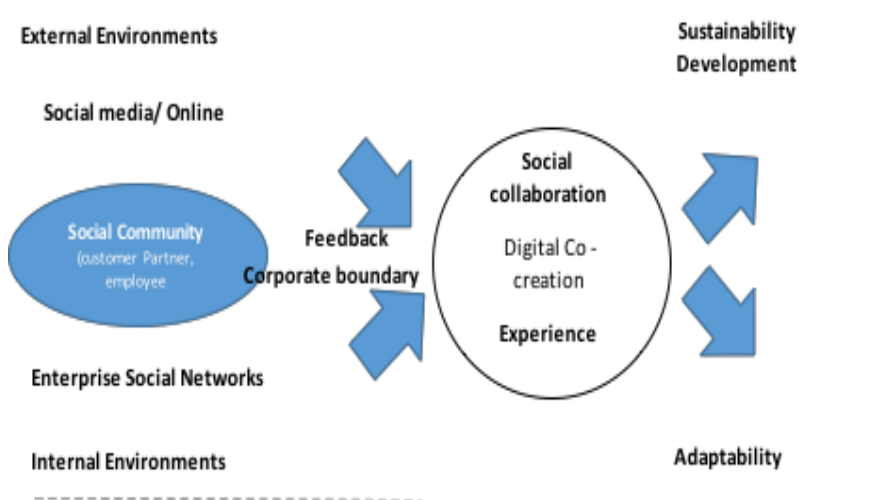

Figure 6. Sustainable Co-creation based on Agility and Experience

(Romero \& Molina, 2009)

The model of sustainability has implications of the firm to focus on the development of digital co-creation based on experience, community, and agility.

\section{Conclusions}

The study have found that sustainability based on agility, communities, and experience models demonstrate how organizational agility, social communities, and customer experience orientation have a significant role in the development of digital co-creation to support for a more sustainable development. The study helps the ICT sector to focus on effective decision making to consider the economic values as well as the social values to provide fast and flexible decisions. This is important in the transformation of performance and to shape the sustainability development. The study contributes towards the initiation of a valuable model of transformation by prioritising programs on organizational agility, social communities, and customer experience orientation. All of which has significant contributions in the development of digital co-creation. Further studies could be expanded through increasing the model to not only social communities but also biosphere variable in relation to the green development model.

\section{REFERENCES}

1. Chincholle, D., Lachize, S., Backstrom, C., \& Eriksson, C. (2013). Crafting UX - designing the user experience beyond the interface. Ericsson Review, 7(2013), 1-8. Retrieved from https://www.ericsson.com/res/thecompany/docs/publications/ericsson_r eview/2013/er-crafting-ux.pdf

2. Arbussa, A., Bikfalvi, A., \& Marquès, P. (2017). Strategic agility-driven business model renewal : the case of an SME. Management Decision, 55(2), 271-293. https://doi.org/10.1108/MD-05-2016-0355

3. Carvalho, A. M., Sampaio, P., Rebentisch, E., Carvalho, J. Á., \& Saraiva, P. (2017). Operational excellence, organisational culture and agility: the missing link? Total Quality Management and Business Excellence, 4(2017), 1-20. https://doi.org/10.1080/14783363.2017.1374833

4. Chakravarty, A., Grewal, R., \& Sambamurthy, V. (2013). Information technology competencies, organizational agility, and firm performance. Information Systems Research, 24(4), 976-997. https://doi.org/10.1287/isre.2013.0500

5. Cohen, J. (1992). Quantitative Methods in psychology: A Power Primer. $\begin{array}{lll}\text { Psychological } \quad \text { Bulletin, } & 112(1), & 155-159 .\end{array}$ https://doi.org/10.1016/j.jorganchem.2011.01.025

6. Crocitto, M., \& Youssef, M. (2003). The human side of organizational agility. Industrial Management and Data Systems, 103(6), 388-397. https://doi.org/10.1108/02635570310479963

7. Fatma, S. (2014). Antecedents and Consequences of Customer Experience Management- A Literature Review and Research Agenda. International Journal of Business and Commerce, 3(6), 32-49.

8. Felipe, C. M., \& Rold, L. (2017). Impact of Organizational Culture Values on Organizational Agility. https://doi.org/10.3390/su9122354

9. Fuller, J. (2010). Refining Virtual Co-creation from a Consumer Perspective. California Management Review, 52(2), 98-122. https://doi.org/https://doi.org/10.1525/cmr.2010.52.2.98

10. Füller, J., Bartl, M., Ernst, H., \& Mühlbacher, H. (2006). Community based innovation: How to integrate members of virtual communities into new product development. Electronic Commerce Research, 6(1), 57-73. https://doi.org/10.1007/s10660-006-5988-7

11. Hair, J. F., Ringle, C. M., Sarstedt, M., \& Vinzi, E. (2014). Editorial Partial Least Squares Structural Equation Modeling: Rigorous Applications , Better Results and Higher Acceptance. Long Range Planning, 46(1-2), 1-12. https://doi.org/10.1109/MCSE.2008.47

12. Hamidi, F., \& Shams Gharneh, N. (2017). Impact of co-creation on innovation capability and firm performance: a structural equation modeling. AD-Minister, 73-90. https://doi.org/10.17230/ad-minister.30.4

13. Latham, J. R. (2013). A framework for leading the transformation to performance excellence part I: CEO perspectives on forces, facilitators, and strategic leadership systems. Quality Management Journal, 20(2), 12-33. https://doi.org/10.1080/10686967.2013.11918095

14. Lemon, K. N., \& Verhoef, P. C. (2016). Understanding Customer Experience Throughout the Customer Journey. Journal of Marketing, 80(6), 69-96. https://doi.org/10.1509/jm.15.0420

15. Loucks, J., Bradley, J., Macaulay, J., Noronha, A., \& Wade, M. (2015). Digital Vortex: How Digital Disruption is Redifining Industries. Global Center for Digital Business Transformation, (June), 1-24.

16. Lu, Y., \& Ramamyrthy, K. (2011). Understanding the Link between Information Technology Capability and Organizational Agility: An Emperical Examination. Management Information Systems Quarterly, 35(4), 931-954. 
17. Mittal, S. (2014). Relationship of Value Co-Creation with Customer Experience and Customer Engagement for Online Fashion Portals in India.

18. Nold, H., \& Michel, L. (2013). The Performance Triangle : A Model for Corporate Agility. Retrieved from https://www.agilityinsights.net/media/archive1/downloads/AgilityInsigh ts-ThePerformanceTriangle.pdf

19. Pérez, L., Dos Santos Paulino, V., \& Cambra-Fierro, J. (2017). Taking advantage of disruptive innovation through changes in value networks: insights from the space industry. Supply Chain Management: An International Journal, 22(2), 97-106. https://doi.org/10.1108/SCM-01-2017-0017

20. Pradhan, R. P., Mallik, G., \& Bagchi, T. P. (2018). Information communication technology (ICT) infrastructure and economic growth: A causality evinced by cross-country panel data. IIMB Management Review, 30(1), 91-103. https://doi.org/10.1016/j.iimb.2018.01.001

21. Ramaswamy, V. (2009). Leading the transformation to co-creation of value. Strategy and Leadership, 37(2), 32-37. https://doi.org/10.1108/10878570910941208

22. Ramaswamy, V. (2011). It's about human experiences...and beyond, to co-creation. Industrial Marketing Management, 40(2), 195-196. https://doi.org/10.1016/j.indmarman.2010.06.030

23. Restuccia, M. (2009). Value Co-Creation Orientation: Conceptualization, Measurement and Impact on Firm Performance.

24. Richter, S., Trier, M., \& Richter, A. (2017). Value co-creation in the digital factory - The empowered role of shop floor workers. In Australian conference on information systems (Vol. 28, pp. 1-12). Retrieved from https://www.acis2017.org/wp-content/uploads/2017/11/ACIS2017_pap er_144_FULL.pdf

25. Romero, D., \& Molina, A. (2009). Value co-creation and co-innovation: Linking networked organisations and customer communities. IFIP Advances in Information and Communication Technology, 307, 401-412. https://doi.org/10.1007/978-3-642-04568-4_42

26. Sasmoko, M, L.W, W, Alamsjah, F., \& Elidjen, E. (2019). The influence of digital customer experience and electronic word of mouth on brand image and supply chain sustainable performance. Uncertain Supply Chain Management, 7(2019), 691-702. https://doi.org/10.5267/j.uscm.2019.4.001

27. Sasmoko, M, L.W, W, Alamsjah, F., Elidjen, E., \& Sasmoko, S. (2018). Digital Transformation in the Age of Industry 4 . 0: Acceleration of Transformational Performance through Business Model Innovation and Co-Creation Strategy in Indonesian ICT Firms Transformación digital en la era de la industria 4 . 0 : Aceleración del. Opcion, 86(86), 2145-2159.

28. Sawhney, O., Verona, G., \& Prandelli, E. (2005). Collaborating to Create: The Internet as Platform for Customer Engagement in Product innovation. Journal of Interactive Marketing, 19(4), 1-14. https://doi.org/10.1002/dir

29. Seethamraju, R., \& Krishna Sundar, D. (2013). Influence of ERP systems on business process agility. IIMB Management Review, 25(3), 137-149. https://doi.org/10.1016/j.iimb.2013.05.001

30. Sharma, S., Conduit, J., \& Rao Hill, S. (2014). Organisational capabilities for customer participation in health care service innovation. Australasian Marketing Journal, 22(3), 179-188. https://doi.org/10.1016/j.ausmj.2014.08.002

31. Shrivastava, P. (2016). Effect of Co-Creation on Customer Experience, Trust and Brand Loyalty. International Journal of Sales \& Marketing Management Research and Development (IJSMMRD), 6(6), 1-14. Retrieved from http://www.tjprc.org/view-archives.php

32. Sjödin, C., \& Kristensson, P. (2012). Customers' experiences of co-creation during service innovation. International Journal of Quality and Service Sciences, 4(2), 189-204. https://doi.org/10.1108/17566691211232918

33. Teece, D., Peteratd, M., \& Leih, S. (2016). Dynamic Capabilities and Organizational Agility. California Management Review, 58(4), 4-9. https://doi.org/10.1525/cmr.2016.58.4.13

34. Trencher, G., Nagao, M., Chen, C., Ichiki, K., Sadayoshi, T., Kinai, M., ... Yarime, M. (2017). Implementing sustainability co-creation between universities and society: A typology-based understanding. Sustainability (Switzerland), 9(4). https://doi.org/10.3390/su9040594

35. Trinh-Phuong, T., Molla, A., \& Peszynski, K. (2010). Enterprise systems and organisational agility: Conceptualizing the link. In ACIS 2010 Proceedings - 21st Australasian Conference on Information Systems (pp. 1-4). Retrieved from http://www.scopus.com/inward/record.url?eid=2-s2.0-84870387687\&p artnerID=40\&md5=ae17d0013c85ef2e21e7d4d50d257dc6

36. Valdez-de-leon, O. (2016). A Digital Maturity Model for Telecommunications Service Providers A Digital Maturity Model for Telecommunications Service Providers, 6(8), 19-32.

37. Vincenza Ciasullo, M., Troisi, O., \& Cosimato, S. (2018). How Digital Doctoral Workshop Naples Forum on Services, 1(514), 1-16.

Platforms Can Trigger Cultural Value Co-Creation?-A Proposed Model. Journal of Service Science and Management, 11(02), 161-181. https://doi.org/10.4236/jssm.2018.112013

38. Wei, Z., \& Xuexun, H. (2010). A research on the relationship between innovation culture, transformational capabilities and transformational performance. In IEEE Explore on 2010 International Conference on Management and Service Science (pp. 1-4) https://doi.org/10.1109/ICMSS.2010.5576400

39. Wüstenhagen, R., Sharma, S., Starik, M., \& Wuebker, R. (2008) Sustainable Innovation and Entrepreneurship: introduction to the volume. In R. Wustenhagen, J. Hamschmidt, S. Shara, \& M. Starik (Eds.) Sustainable Innovation and Entrepreneurship (1st Editio, pp. 1-21). Cheltenham, UK; Massachusetts, USA: Edward Elgar Publishing Limited. https://doi.org/10.4337/9781848441552

\section{AUTHORS PROFILE}

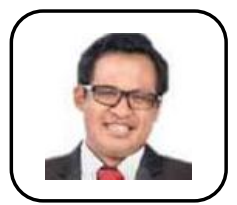

First Author Leonardus W Wasono Mihardjo is a Doctor candidate in Management at Bina Nusantara University, West Jakarta, Indonesia. His research has attracted funding award from Indonesia Ministry of research and higher education in 2019, as well as awarded as best paper in Malaysian conference 2018 . Currently, he is a director of Financial and Business Partner at PT Telekomunikasi Indonesia International (Telin) focus on financial and development of Human capital. He is also chairman of PT Telin Australia and Board member of Telin Singapore. He has more than 20 years in Telecommunication Industry with 12 years in Telkomsel. His research interest includes digital transformation, business model innovation, technology, digital leadership and strategic management Orcid ID ; orcid.org/0000-0002-3820-4960

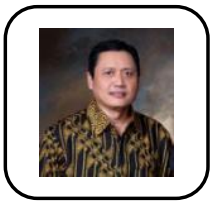

\section{Second Author Sasmoko}

Sasmoko is a Professor of Research Methods of Faculty of Humanities at Bina Nusantara University, Jakarta. He is currently working at the RIG-Education Technology, Binus University. Their most recent publication is 'Applying indonesian teacher engagement index (ITEI) apps: Self-diagnostic apps for teachers in Indonesia', including the use of Artificial Intelligent for education and social Science. His researches have attracted funding award from Indonesia Ministry of research and higher education and also from Bina Nusantara university.

His research interest includes teaching methods, teacher education and educational assessment, including the use of Technology for Education Orcid ID: orcid.org/0000-0001-9219-9237

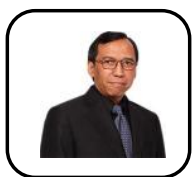

Third Author Firdaus Alamsjah is currently the Executive Dean and Provost of the Bina Nusantara Business School, where he also serves as a faculty member. He is a managing partner at Binus Consulting and Training. He has more than 20 years of extensive experience is in consulting, training, and teaching, which complements his research interests in strategy execution, supply-chain management and business process management, digital technology and social science. He earned his PhD in Industrial Engineering and his MSIE from the University of Houston, USA. His bachelor's degree in mechanical engineering was completed at ITB Bandung

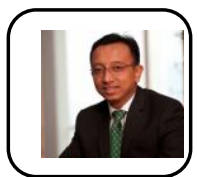

Fourth Author Dr. Riza A.N. Rukmana is currently a senior lecturer of Telkom University, a leading university in Indonesia focusing on telecommunication related studies. $\mathrm{He}$ is also Vice President of Marketing and Business Intelligence at PT Telkom Indonesia International (2015-current). He has more than 22 years experiences in Indonesia telecommunication industry. He joined Telkom Indonesia International since 2011 as a VP of Corporate Strategic Planning (2011-2015). Before that he was a Telkom employee since 1996 to 2011. He earned his bachelor's in industrial engineering from STT Telkom in 1995 and master's degree on Marketing Management from Padjajaran University, Bandung, Indonesia in 1998, Dr. Riza completed his Ph.D. in Management and Economics Studies at Padjajaran University, Bandung, Indonesia in 2005. He has numerous consulting experiences in Strategy Formulation and Market Research

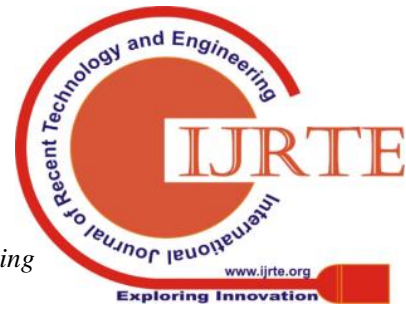

